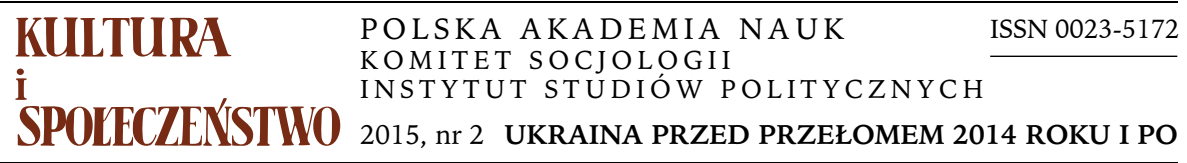

ALLA KARNAUKH

Uniwersytet Pedagogiczny im. Komisji Edukacji Narodowej w Krakowie

\title{
ŚWIADOMOŚĆ NARODOWA W ZMIENIAJĄCYM SIĘ SPOŁECZEŃSTWIE UKRAIŃSKIM NA PRZYKŁADZIE UKRAIŃCÓW, ROSJAN I BUŁGARÓW NA ZAPOROŻU
}

Świadomość narodowa, mimo cechującej ją wieloznaczności, jest zapewne jednym z najważniejszych problemów przemian społecznych na Ukrainie po 1991 roku. W tym państwie zachodziły od dawna, a w ostatnich dziesięcioleciach uległy znaczącym przemianom, procesy kształtowania się i krystalizacji świadomości narodowej. Kluczem do bliższego przedstawienia tych zmian jest między innymi wyjaśnienie złożoności procesów narodotwórczych na wewnętrznych pograniczach Ukrainy.

Poszukiwanie odpowiedzi na pytanie, w jakim kierunku zmierza proces kształtowania świadomości narodowej obywateli Ukrainy po odzyskaniu niepodległości, legło u podstaw realizacji w latach 2010-2012 projektu badawczego na Zaporożu ${ }^{1}$, które jest specyficznym obszarem pogranicza ukraińsko-rosyjskiego. Region Zaporoża (południowo-wschodnie tereny Ukrainy, między Donieckiem a Krymem) wyróżnia się pod względem historycznym i narodowościowym: w czasach radzieckich daleko posunięte procesy rusyfikacji objęły również Zaporoże, lecz północne tereny dzisiejszego obwodu zaporoskiego historycznie są związane z powstaniem Siczy Zaporoskiej jako formy współżycia społecznego i centrum kultury ukraińskich Kozaków.

Adres do korespondencji: alla.karnaukh@vp.pl

\footnotetext{
${ }^{1}$ Badania były finansowane ze środków na naukę w latach 2010-2012 jako projekt badawczy promotorski pt. „Świadomość narodowa po komunizmie w wieloetnicznych zbiorowościach na Zaporożu", nr N N116 318639 (umowa nr 3186/B/H03/2010/39), realizowany pod kierownictwem dra hab. Dariusza Wojakowskiego. Niniejszy artykuł jest syntezą analiz i wyników badań z pracy doktorskiej, która ukazała się jako monografia pt. Pomiędzy ukraińskościa a sowieckością. Ukraińcy, Rosjanie i Bułgarzy na Zaporożu, Nomos, Kraków 2015.
} 
Zasadniczym przedmiotem badań były wieloetniczne społeczności lokalne. Zaprezentowane tu ujęcie stanowi próbę spojrzenia na zmieniającą się Ukrainę $z$ perspektywy jednostki, z uwzględnieniem jej pochodzenia etnicznego, wieku, doświadczenia historycznego itp. Taki punkt widzenia pozwala uchwycić różnorodne sposoby doświadczania zmian społecznych (indywidualne reakcje na nie), a zarazem wziąć pod uwagę szereg zmiennych, takich jak społeczne, historyczne czy kulturowe uwarunkowania regionu. Może być pomocny w wyjaśnieniu dotychczas nieznanych prawidłowości kształtowania świadomości narodowej jednostki przez odwoływanie się do indywidualnych decyzji, nierzadko opartych na bardzo osobistych wyborach, uwzględniających miejsce lub region zamieszkania i jego historyczną przeszłość.

Podczas badań terenowych zostały zastosowane różne techniki badawcze: wywiady pogłębione $z$ mieszkańcami badanych miejscowości oraz ekspertami lokalnymi, obserwacja, analiza zastanych dokumentów. Miejsca przeprowadzenia badań wybrano według klucza narodowościowego — były to trzy wsie zróżnicowane narodowościowo (Jurjewka, Bogorodickoje, Zelenowka) oraz najbliższe miasto (Berdiańsk) jako miejsce migracji i wytworzonego tam zróżnicowania kulturowego mieszkańców. O wyborze tych miejscowości zadecydował procentowy udział wśród ich mieszkańców określonych grup etnicznych najliczniej reprezentowanych na badanym terenie, czyli Ukraińców, Rosjan i Bułgarów. Przeprowadzono 100 wywiadów, po $20 \mathrm{w}$ miejscowościach wiejskich oraz $40 \mathrm{w}$ mieście. Liczba ekspertów lokalnych, z którymi zostały przeprowadzone rozmowy, to ogółem 17 osób.

\section{UKRAINA POMIĘDZY KULTUROWĄ A OBYWATELSKĄ KONCEPCJĄ NARODU}

Podrozdział ten zawiera odwołanie do dylematów definicyjnych dotyczących tak nieostrego pojęcia, jakim jest „naród” 2 . Po ponad dwudziestu latach niepodległości Ukrainy wśród polityków i jej obywateli nadal nie ma zgodności co do pojęcia „narodu/nacji ukraińskiej” (zob. Kasjanow 1999, s. 177). Chodzi przede wszystkim o wskaźniki przynależności narodowej, które powinien reprezentować Ukrainiec, żeby był uznawany za takiego. Ukraina waha się między dwiema koncepcjami narodu - etniczną/kulturową i państwową/obywatelską ${ }^{3}$. Kijow-

\footnotetext{
2 Jego podtytuł zawiera pewną skrótową treść i odnosi się do źródeł i modeli procesów powstawania narodów, na przykład etniczno-genealogiczny, czyli kulturowy versus terytorialno-polityczny — państwowy (zob. Kłoskowska 1996; Lewandowski 2004; Altermatt 1998; Gellner 1991).

${ }^{3}$ Nawet Konstytucja Ukrainy (1996) nie wyjaśnia tak istotnych pytań, jak: Czym jest naród ukraiński? Co to jest nacja? Czy uzasadnione jest synonimiczne używanie tych dwóch pojęć? W głównym akcie prawnym państwa ukraińskiego używa się zarówno określenia „ukraińska nacja” (ukr. українська нація), jak „naród ukraiński” (ukr. український народ). Czytając postanowienia konstytucyjne, można zauważyć, że termin „naród ukraiński” jest używany raczej w znaczeniu „obywatele Ukrainy niezależnie od narodowości”, natomiast termin „ukraińska nacja” jako etniczna grupa (szerzej zob. Pawluczuk 1998, s. 66-68; Kasjanow 1999, s. 24, 177; Bałuszok 1999).
} 
ski historyk Heorhij Kasjanow (1999, s. 177); już dość dawno wysunął hipotezę, iż „wybór koncepcji identyfikacji narodowej (etnicznej lub politycznej) zależy w dużej mierze od typu elit, które przychodzą do władzy". W moim przekonaniu dla społeczeństwa ukraińskiego, a także dla państwa, dylemat wyboru między polityczną/obywatelską a kulturową/etniczną koncepcją narodu ukraińskiego, który notorycznie powraca przy kolejnych zmianach prezydentów i rządów, grozi destabilizacją. W praktyce współczesna elita polityczna stara się uwzględniać zarówno jedną, jak i drugą koncepcję narodu, próbując osiągnąć pewien kompromis, wypracowując własną drogę budowy narodu ukraińskiego (stąd pewien chaos terminologiczny podczas używania określeń „naród-nacja”, pozwalający na dowolną interpretację). Zdaje sobie ona sprawę $z$ tego, $\dot{z}$ e ostateczne opowiedzenie się po stronie jednej czy drugiej koncepcji zagraża politycznej stabilności oraz terytorialnej całości Ukrainy. Przykładem tego rodzaju wyzwań dla państwa był między innymi Euromajdan w 2013/2014 roku, a obecnie jest nim trwający od ponad roku konflikt zbrojny na wschodnich terenach Ukrainy (Krym, Donieck, Ługańsk) ${ }^{4}$.

Idea niezależnej Ukrainy jako państwa etnicznych Ukraińców, w którym język ukraiński i kultura zaczną odgrywać dominującą rolę, jest popularnym wątkiem w mediach i dyskursie politycznym, między innymi jako wyraz protestu przeciwko wpływom „imperialnej” kultury rosyjskiej. Jednak całkowite przyjęcie etnicznych wyznaczników przynależności narodowej wykluczyłoby z członkostwa $\mathrm{w}$ narodzie ukraińskim znaczne rzesze ludności różniącej się językiem i kulturą (np. Rosjan, Białorusinów, Bułgarów, Polaków i in.).

Badacze często uznają za naturalne, że ludzie posługujący się tym samym językiem szukają własnej tożsamości politycznej. Rzeczywiście, często zakłada się, że narody, w których skład wchodzą różne grupy językowe, stanowią kruche kompromisy i w razie kolejnych kryzysów i zawirowań mogą się łatwo rozpaść (zob. Billig 2008, s. 44-45). Taki sposób myślenia nie jest nowy. W XVIII wieku Johann Herder (na podstawie jego prac powstało wiele koncepcji i idei, z których również korzystali ukraińscy intelektualiści) stwierdził, że fundamentem narodu, jego duchem, jest język. Nie możemy jednak zadowalać się opinią, że jest to naturalne, iż ci, którzy mówią tym samym językiem, będą chcieli organizować się w narodowe ugrupowania ${ }^{5}$.

\footnotetext{
${ }^{4}$ Cechą wspólną wszelkich nastrojów nacjonalistycznych/patriotycznych jest ich nasilanie się w sytuacjach kryzysowych. W środkach masowego przekazu często wykorzystuje się motyw różnych podziałów Ukrainy i narodu ukraińskiego, argumentując, że przy wzroście temperatury życia politycznego i odpowiednim rozpaleniu sytuacji nacjonalizmy mogą odżyć z ogromną siłą i wymknąć się spod kontroli.

${ }^{5}$ Jeśli państwo respektuje kulturową różnorodność, nie trzeba rozdzielać grup narodowościowych ani tworzyć mniejszych państw narodowych. Ludzie decydują się na jedną bądź drugą tożsamość tylko wtedy, gdy nie mają innego wyboru. W niektórych europejskich krajach dwojaka czy wieloraka tożsamość jest czymś zupełnie normalnym, występuje jako wybór, na który pozwala naród państwowy (np. Szwajcaria).
} 
„Błędem jest zawsze — pisze Benedict Anderson (1997, s. 134) — traktowanie języków w taki sposób, w jaki traktują go niektórzy ideolodzy nacjonalizmu - jako emblematu narodowości, jak flagi, stroje, tańce ludowe itd. Rzeczą nieporównanie ważniejszą w tym wypadku jest jego zdolność generowania wspólnot wyobrażonych, budowania solidarności. Język nie jest instrumentem wyłączania: w zasadzie każdy nauczyć się może dowolnego języka". Język, choć zwykle ma w tworzeniu poczucia narodowego udział bardzo znaczący i w praktyce służy jako znak rozpoznawczy narodowości w kontaktach międzyetnicznych i międzynarodowych, nie jest warunkiem powstania narodu i nie jest elementem absolutnie koniecznym do identyfikacji narodowej jednostek. Wybór języka nie jest więc (nie musi) być tożsamy z wyborem narodowości.

Podsumowując rozważania tego podrozdziału, odwołam się do zdania Heorhija Kasjanowa (1999), który dokonawszy analizy ukraińskiego procesu narodotwórczego dochodzi do wniosku, iż „bycie Ukraińcem” jest wyznaczane na podstawie własnej świadomości i stosunku do państwa. Język i religia odgrywają znacznie mniejszą rolę: można posługiwać się na co dzień językiem rosyjskim, ale w dokonywanych wyborach politycznych być Ukraińcem. Sedno sprawy leży więc w świadomości. Na podstawie tak skonstruowanych wywodów można zaproponować tezę o kształtowaniu się narodu ukraińskiego jako ws pólnoty wyobrażonej w ujęciu Benedicta Andersona (1997) ${ }^{6}$.

\section{DYLEMATY ŚWIADOMOŚCI NARODOWEJ}

W rozważaniach współczesnych ukraińskich badaczy nad przynależnością narodową/etniczną dominuje pogląd, iż każdy naród charakteryzuje się pewnymi cechami zarówno obiektywnymi, jak subiektywnymi, wśród których można wyróżnić cechy dominujące, dlań właściwe. Podział na subiektywne i obiektywne cechy narodu pozostaje bardziej warunkowy i zależy od wewnętrznych czy zewnętrznych czynników powstawania oraz trwania danego narodu. Natomiast oczywista jest dla wielu badaczy obecność pewnej subiektywnej cechy, decydującej dla istnienia narodu (współczesnego narodu) - w zależności od przyjętej terminologii może to być „solidarność grupowa”, „poczucie wspólnoty”, „codzienny plebiscyt”, „świadomość narodowa” — ważne, by określona wspólnota posiadała samoświadomość bycia narodem (zob. Kasjanow 1999, s. 37).

\footnotetext{
${ }^{6}$ Warto też odwołać się do Ursa Altermatta (1998, s. 54), który zaznacza: „Narodem są ludzie, którzy uważają się za naród - tak można by to tautologicznie sformułować. Naród nie opiera się na faktach, lecz na tym, co ludzie uważają za fakty. Błędem byłoby jednak, gdybyśmy uznali naród za czystą fikcję. Naród obejmuje ludzi, którzy w toku dziejów przypadkiem zamieszkali obok siebie. Zgodnie ze znanym twierdzeniem, naród jest wspólnotą, której członkowie na skutek błędu historycznego wierzą we wspólne pochodzenie i mają wspólnego wroga".
} 
„Naród bez świadomości narodowej nie istnieje” — jest to teza, którą wysuwa w swoich rozważaniach nad społeczeństwem Jerzy J. Wiatr (1973, s. 380). Oznacza to, że sama polityczna przynależność państwowa nie przesądza o występowaniu poczucia narodowego, podobnie jak brak wspólnej przynależności państwowej nie wyklucza istnienia solidarności narodowej. Wiatr uznaje wielką rolę subiektywnej strony więzi narodowej, ale bynajmniej nie sprowadza tej więzi do świadomości: „Więź subiektywna, świadomość narodowa, nie jest niczym innym, jak tylko czynnym odbiciem obiektywnej więzi narodowej, której korzenie tkwią we wspólnocie losów dziejowych. Dlatego właśnie świadomość narodowa może być traktowana jako empiryczny wskaźnik obiektywnych procesów, od których zależy uformowanie się więzi narodowej" (Wiatr 1973, s. 393-395). Świadomość narodowa w tym ujęciu jawi się jako rezultat dokonującej się lub dokonanej integracji narodowej. Jest to świadomość własnej odrębności jako narodu, świadectwo tego, że ma się do czynienia z mniej lub bardziej dojrzałym narodem.

W związku z powyższym świadomość narodowa w opisanym projekcie badawczym jest rozumiana jako:

—świadomość historyczna (mogą tu się pojawić kwestie lokalnej historii, więzi z przestrzenią i społecznością);

— tożsamość jednostki (ustalenie tego, co w rozumieniu jednostki kryje się pod deklaracją identyfikacyjna);

- kompetencje kulturowe jako zespół nabytych cech i zdolności umożliwiających swobodne uczestnictwo w danej kulturze;

— relacje "swój-obcy" (chodzi tu przede wszystkim o to, jaki jest stosunek jednostki do swojej grupy i jej kultury oraz w jakiej relacji pozostaje wobec innych tożsamości narodowych i kultur).

W języku polskim używa się często, oprócz terminu „tożsamość”, pojęcia „świadomość narodowa” (Babiński 1997, s. 88). W związku z tym wyłania się kilka zasadniczych pytań: Czy świadomość to składnik tożsamości? A może jest to identyfikacja narodowa? Czy identyfikacja to tożsamość? Można spostrzec, że pojęcia te często są mylone czy nadużywane. Nie wydaje się, aby bez uproszczeń możliwe było ich jednoznaczne rozdzielenie. Dlatego pojęcie świadomości narodowej jest tu stosowane jako pojęcie szersze niż tożsamość, pozwalające uporządkować wielość informacji, których właśnie dostarczają tożsamość jednostki i kompetencje kulturowe. Innymi słowy, świadomość narodowa jest tu definiowana jako wzajemnie powiązana, zintegrowana całość treści wartości, idei, postaw charakterystycznych dla danej zbiorowości lub społeczeństwa w całości ${ }^{7}$.

\footnotetext{
7 Więcej na temat wyborów definicyjnych między świadomością narodową a tożsamością zob. Karnaukh 2015, s. 41-45.
} 


\section{CO TO ZNACZY BYĆ UKRAIŃCEM?}

Projekt badawczy opierał się na spojrzeniu na kwestie świadomości narodowej „od dołu”, na przyjęciu punktu widzenia mieszkańców społeczności lokalnych odpowiadających na podstawowe pytanie „Co to znaczy być Ukraińcem?”, a także na pytania mu towarzyszące. Oto zaledwie kilka cytatów z szerszych wypowiedzi respondentów:

Wszyscy jesteśmy Ukraincami. Czy mieszkańcy zachodniej Ukrainy maja prawo czuć sie Ukraińcami, a my nie, ponieważ mówimy po rosyjsku!? Absurd. Tak, nasz region jest wielonarodowy, mówimy po rosyjsku, ale jesteśmy... czujemy się Ukraińcami. [...] By być Ukraińcem należy znać język, kulture, tradycje, nie wystarczy tylko mówienie „jestem Ukraincem", należy to czuć... I ja to czuje (K, R, 47 lat, Jurjewka) ${ }^{8}$.

Uważam, że każdy powinien mieć świadomość bycia Ukraińcem. Każdy obywatel państwa... [...] O ile jest świadomość bycia cztonkiem danego narodu, poczucie dumy narodowej, ten człowiek jest przedstawicielem tego państwa i narodu. Jeżeli tego nie ma, jeżeli miejsce zamieszkania jest traktowane tylko jako miejsce mieszkania, ten człowiek nic nie zrobi dla państwa - nie jest $w$ stanie. Jeżeli jest inaczej, wtedy każdy $z$ nas stara sie zrobić coś, by to miejsce, gdzie jesteśmy, byto lepsze, by się rozwijato, byto piękne i żywe. [...] Świadomość narodowa, nikty patriotyzm - to sa problemy Ukrainy, tzn. stąd wiele wspótczesnych problemów. Brakuje konsekwentnej polityki: to zmieniamy jezyk, to zmieniamy historię... Mtode pokolenie dopiero się ksztattuje jako czesśc narodu ukraińskiego, oby kolejna jakaś zmiana polityczna tego nie zmienita i nie zatrzymata (M, U, 40 lat, Jurjewka).

Kim się czujesz? — Ciężkie pytanie... najbardziej mi się podoba rosyjski, jest mi bliski... ale... Ja... jestem Ukraińcem. Mieszkam na Ukrainie. Mam obywatelstwo... Nawet nie wiem, za kogo się uważam... Nie mogę się uważać za Butgara, chyba że wyglad zewnętrzny jakoś o tym świadczy. Nie mogę się uważać za Bułgara, dlatego że... jakby rozumiem, że ja nie mówię, nie znam języka... nie czuje jakiejśs szczególnej więzi. [...] Mieszkam na Ukrainie i uważam się za Ukrainca, tak czuje (M, B, 25 lat, Zelenowka).

$\mathrm{Z}$ mnogości materiału badawczego dało się wyodrębnić trzy charakterystyczne znaczenia własnej przynależności do narodu ukraińskiego ${ }^{9}$. Są one

\footnotetext{
8 Fragmenty cytowanych wypowiedzi opisano podając: płeć respondenta $(\mathrm{K}, \mathrm{M})$, pochodzenie (rosyjskie - R, ukraińskie - U, bułgarskie - B), wiek i miejsce zamieszkania.

9 Celem przeprowadzonych badań było nie dotarcie do jednolitego, dominującego wzoru bycia Ukraińcem, ale wydobycie podstawowych wariantów poczucia przynależności i prezentacji siebie jako członka określonego narodu, zbiorowości etnicznej czy innej. Nie wszystkich wariantów w ogóle, ale takich typów, które można uznać za charakterystyczne. Przy takim ujęciu nie jest, oczywiście, możliwa pełna realizacja zasady „nasycenia”. W wyniku przeprowadzonej analizy materiału badawczego ujawniły się kwestie dodatkowe, warte głębszego zbadania w przyszłości. Trzeba będzie skupić się na sposobie kształtowania świadomości narodowej obecnie najmłodszego pokolenia, które może być odmienne. Pokolenie powojenne, pokolenie pierestrojki oraz postkomunistyczne dzielą spora różnica wieku oraz różne doświadczenia systemowe. Jednak większość osób badanych wciąż pozostaje jakby pomięd zy przeszłością a współczesnością, czyli po międ zy „sowieckością" a ukraińskością.
} 
bardziej złożone, lecz w celach praktycznych należy zastosować zabieg uproszczenia złożoności typów narodowej identyfikacji jednostek:

(1) Mieszkam na Ukrainie,

(2) Jestem obywatelem Ukrainy,

(3) Uważam się za Ukraińca.

Wyodrębnienie tych kategorii jest dosyć względne, ponieważ 1 i 2 oraz 2 i 3 pozostają komplementarne względem siebie, a granica między tymi kategoriami jest umowna. Określenie siebie jako „mieszkańca Ukrainy”, „obywatela” bądź świadomego członka społeczności ukraińskiej spotyka się zarówno wśród ukraińskiej, jak bułgarskiej i rosyjskiej grupy etnicznej, niezależnie od kategorii wiekowej respondentów. Trudność polega na niemożności dokonania mniej lub bardziej precyzyjnej klasyfikacji. Poniższą tabelę należy potraktować jako szkicowe pokazanie rozkładu modeli świadomości narodowej wśród osób badanych.

Tabela 1

Modele świadomości narodowej wśród osób badanych

\begin{tabular}{|l|c|c|c|}
\hline Modele Pochodzenie etniczne & $\begin{array}{c}\text { Pochodzenie } \\
\text { skraińskie }\end{array}$ & $\begin{array}{c}\text { Pochodzenie } \\
\text { rosyjskie }\end{array}$ & $\begin{array}{c}\text { Pochodzenie } \\
\text { bułgarskie }\end{array}$ \\
\hline $\begin{array}{l}\text { Mieszkam na Ukrainie } \\
\text { Mieszkam na Ukrainie/Jestem obywatelem }\end{array}$ & 4 & 3 & 8 \\
$\quad$ Ukrainy & 8 & 7 & - \\
Jestem obywatelem Ukrainy & 11 & 15 & 9 \\
Jestem obywatelem Ukrainy/Uważam się za & 2 & 9 & 9 \\
$\quad$ Ukraińca & 20 & 4 & 8 \\
\hline Uważam się za Ukraińca & & & \\
\hline
\end{tabular}

Źródło: opracowanie własne na podstawie analizy materiału badawczego (więcej szczegółów zob. Karnaukh 2015, s. 248-249).

Najczęściej deklarowana była pozycja 2 (Jestem obywatelem Ukrainy) i 3 (Uważam się za Ukraińca). Deklaracje „bycia mieszkańcem Ukrainy” są połączone z kategorią obywatelskości oraz często wiążą się z poczuciem braku realizacji życiowej lub stratą dotychczasowego stanu posiadania i pozycji społecznej na skutek transformacji ustrojowej.

Wie Pani, dlaczego tak porównuję, wracam do tego, jak $i$ co byto wtedy [w czasach Związku Radzieckiego], może się mylę, może nie mam racji, ale jest to moje zdanie, tak czuję: wie Pani, jakoś się pogubiliśmy. Tak wiele krzyczeliśmy „za wolna Ukrainę”, tak dużo pragnęliśmy tej wolności, swobody, tylko być swobodnymi od czego?! W Związku Radzieckim była ideologia, która... Ja rozumiem, że byto ciężko, byty trudne okresy. Ale byliśmy szczęśliwi [...]. Dlaczego nie czuję się Ukrainka?! Ponieważ z jednej strony Ukraina-Rosja zawsze byty jak bracia, a teraz te różne informacje: Bandera - bohater Ukrainy. Mieszaja, mieszaja w glowach ludzi [...]. Z drugiej strony wolność powinna była zagwarantować odpowiedni poziom życia (K, U-R, 44 lata, Berdiańsk). 
Analizując wszystkie elementy składowe świadomości narodowej osób, które określiły się jako „mieszkańcy” lub „obywatele” ( $\mathrm{z}$ formalnego punktu widzenia), należy zaznaczyć, że ukraińska identyfikacja państwowa nie jest przez nich odrzucana, ale także nie jest podkreślana. Mają oni własne zdanie na temat narodu ukraińskiego, które jest zgodne $z$ dominującą $w$ tym regionie koncepcją narodu (społeczeństwa) obywatelskiego. Problem polega na identyfikacji z państwem, a właściwie polityką państwową i niskim stopniu patriotyzmu.

Mam takie wrażenie, że Parlament Ukrainy ma własne życie, gdzie panuja własne reguty gry, a naród Ukrainy - ma własne życie, problemy i sposoby na ich rozwiazywanie. I to jest wtaśnie problem Ukrainy i Ukraińców. Nie to, ̇̇e ktoś jest Rosjaninem czy Ukraińcem, czy jeszcze kimś, nie problem języka, tylko problem państwowości... (K, U-R, 44 lata, Berdiańsk).

Ukraina to nasza ojczyzna, pierwsza ojczyzna, ale w okresie swojej niepodległości niewiele zrobiła dla nas, dla Ukraińców. Totalna korupcja, brak przebicia, bezrobocie. Nie oszukujmy się, wybieram ojczyznę swoich przodków, ponieważ mam taka możliwość [...]. Jeżeli będę miat taka możliwość, zostanę tam. Traktuję taka decyzje jako lepszy start życiowy (M, B, 24 lata, Zelenowka).

Na pierwszym miejscu znajduje się jednak kategoria 3: „Uważam się za Ukraińca". Oznacza to świadomość przynależności narodowej, pozytywne tego wartościowanie, odczuwanie dumy narodowej, poszanowanie kultury narodowej, co nie koliduje $\mathrm{z}$ częstą $\mathrm{w}$ tym przypadku biwalencją, a nawet poliwalencją (Kłoskowska 1996). Kategoria „obywatel”, która również zajmuje znaczącą pozycję, jest traktowana na dwa sposoby: pojmowanie obywatelskości jako „obiektywnej ukraińskości” (formalnej przynależności do państwa ukraińskiego) oraz jako pozytywne wartościowanie i posiadanie dumy narodowej. Kultura ukraińska w sytuacjach codziennych nie jest zjawiskiem powszechnym, ale oceniana jest pozytywnie (język, tradycyjność świąt itd.). Znajomość języka ukraińskiego, w opinii osób badanych, jest ważnym postulatem, nie jedyną, ale jedną z norm tożsamości narodowej. W rzeczywistości społecznej faktyczna realizacja tego postulatu nieco odbiega od deklaracji, a jednak istotna tu jest pozytywna jego ocena.

Człowiek, jeżeli mieszka na Ukrainie — on już jest Ukraińcem, tylko nie powinien upokarzać innych narodów. Mówi się, że jeżeli jesteś Ukraincem, powinieneś mówić w języku ukrainskim. Zgadzam się i popieram. Ale na takiej zasadzie, iż sa stworzone warunki ku temu, żeby stopniowo i rozsądnie wprowadzać język ukrainski w sfere oficjalna, żeby osoby starsze miaty możliwość oswojenia się z nowym dla nich językiem. Język powinien znać każdy, ale czy będzie to dla nich język ojczysty, czy język komunikacji codziennej, czy inny — każdy podejmuje decyzje samodzielnie (M, B, 54 lata, Zelenowka).

Ukrainiec... hm... wedtug narodowości... hm... języka... stowiańska uroda... - na przykład Bułgarzy się różnią od Ukrainców; ale równie dobrze wszyscy jesteśmy pracowici [...]; wedtug wiary - grekokatolicy to już nie, przodkowie nasi byli prawostawni. [...] Pochodzę z ukraińskiej, kozackiej rodziny. Ale jest mi wszystko jedno, kto jakie ma pochodzenie - jaka różnica?! Moim zdaniem wszystkie narodowości, które tu sa, one 
tworza naród Ukrainy. Nie naród ukraiński, lecz naród Ukrainy. [...] Znam się na kulturze lokalnej, poznałem trochę kulturę Butgarów i nasza, ale po tylu latach już się nie da powiedzieć, jakie elementy do kogo należa, wszystko jest wspólne (M, U, 64 lata, Jurjewka).

W większości sytuacji społecznych i osobistych członkowie badanych społeczności jednak funkcjonują w ramach pewnej wielokulturowości, mniej lub bardziej zauważalnej na co dzień. Chodzi o to, że elementy innych kultur obecnych w badanym regionie częściej są widoczne przede wszystkim „od święta”. Nie ma tu sprzeczności między deklaracją przynależności do narodu ukraińskiego a nieużywaniem bądź niepełną znajomością języka ukraińskiego czy funkcjonowaniem na pograniczu kultur ${ }^{10}$. Ważniejsza jest ocena i identyfikacja $z$ narodem ukraińskim niż faktyczne uczestnictwo w jego kulturze.

$\mathrm{Na}$ podstawie powyższych rozważań można sformułować konkluzję, iż czynniki subiektywne dla określenia przynależności narodowej zdaniem osób badanych same $\mathrm{w}$ sobie nie są wystarczające. Jednocześnie $\mathrm{w}$ ich mniemaniu również tzw. czynniki obiektywne, jak język i etniczne pochodzenie, nie są dostateczną gwarancją ukształtowania wspólnoty narodowej. Wśród badanych panuje przekonanie, że wspólne korzenie etniczne zbiorowości nie są tym czynnikiem w procesie narodotwórczym, na którego podłożu zawsze i nieuchronnie dochodzi do powstania jednego narodu. Innymi słowy, twierdzą oni, że przemiana grupy etnicznej $\mathrm{w}$ naród wymaga od jednostek pracy i woli jedności. W wypowiedziach dało się również zauważyć istotne znaczenie państwa jako instytucji zespalającej mieszkańców/obywateli. Sądzę, że na Zaporożu poczucie bycia częścią narodu ukraińskiego, który posiada własne niepodległe państwo, w przyszłości będzie odgrywało jeszcze większą rolę i miało większe znaczenie. Powstanie niepodległej Ukrainy w 1991 roku oraz zmiany społeczne, polityczne, kulturowe, które temu towarzyszyły, coraz bardziej widoczne w ostatnich latach, wzmocniły tożsamość narodową pokolenia pierestrojki oraz pokolenia postkomunistycznego. Ponieważ przemiany te na przedstawicieli najmłodszego pokolenia oddziaływały od pierwszych lat ich życia, sądzę, że po

\footnotetext{
10 Na podstawie definicji pogranicza Antoniny Kłoskowskiej (1996) za podstawowe cechy pogranicza ukraińsko-rosyjskiego można uznać: długotrwałe sąsiedztwo, mieszane małżeństwa, dwujęzyczność, wspólne elementy kultury, nawet wspólne poczynania gospodarcze, wspólna historia obszarów pogranicza i nieustanne ścieranie się dwóch języków (ukraińskiego oraz rosyjskiego) o relatywnie lepszą pozycję w społeczeństwie. Pozostający w bliskich relacjach mieszkańcy pogranicza podzielają tradycje i wartości co najmniej dwóch kultur tam dominujących (duże jest podobieństwo obyczajów świątecznych, następuje również wymiana kulturowa, istnieje mniej lub bardziej widoczna płynność między grupami etnicznymi, związana $z$ istnieniem małżeństw i rodzin mieszanych etnicznie). Można powiedzieć, iż na Zaporożu mamy do czynienia z grupą osób zintegrowanych w ramach określonego „modelu kultury ukraińskiej”, która jest przede wszystkim rosyjskojęzyczna, nie ogranicza się zatem do dorobku wytworzonego lub zapisanego w języku ukraińskim. Pogranicze ukraińsko-rosyjskie to przykład kształtowania jednej kultury wzbogaconej o elementy innych kultur obecnych tu od wieków (rosyjskiej, bułgarskiej, polskiej, niemieckiej, greckiej, żydowskiej i in.) (więcej zob. Karnaukh 2015, rozdz. 6).
} 
zbadaniu reprezentantów tej kategorii wiekowej teza o umacnianiu się tożsamości narodowej znalazłaby tym silniejsze potwierdzenie ${ }^{11}$.

Naród ukraiński od czasu uzyskania niepodległości przechodzi istotny etap przewartościowywania podstaw i kryteriów swej odrębności i tożsamości. Proces ten odbywa się być może wolniej, niż by się spodziewano czy zakładano, ale na podstawie przeprowadzonych badań da się jednoznacznie stwierdzić, że mamy do czynienia $z$ ukształtowanym narodem. Upadek komunizmu i pierwsze piętnaście lat niepodległości były okresem przełomowym - przewartościowanie własnej tożsamości dopiero następuje w ostatnich latach, a za punkt wyjściowy można przyjąć wybory w 2004 roku oraz wydarzenia im towarzyszące. Najwyraźniej społeczeństwo ukraińskie, na co wskazują przykłady osób badanych, stanowi taki typ społeczeństwa, w którym następuje trwałe, zintegrowane połączenie obywatelstwa oraz innych form tożsamości społecznych i kulturowych (zob. Sadowski 2006, s. 35).

Obywatelstwo jest instytucjonalną formą solidarności. Pojęcie to odnosi się do szczególnej kategorii stosunków między ludźmi, którą można i należy wyraźnie odróżnić od kategorii stosunków ekonomicznych (Szacki 1997, s. 29). Konstytuuje ono i wyraża pełne formalne członkostwo i więzi między jego posiadaczami i państwem, bazuje na przynależności do państwa lub narodu, bądź jednego i drugiego, i nadaje jednostce tożsamość obywatela. Jest to teoretyczny sposób postrzegania obywatelskości. W praktyce (sądząc na podstawie wypowiedzi osób badanych) różnie to bywa. Są tacy, którzy, wskazując na obywatelskość, nie odczuwają większej solidarności z współobywatelami i lojalności wobec państwa, o czym była mowa wyżej. W rzeczy samej posiadanie obywatelstwa nie musi iść $\mathrm{w}$ parze $\mathrm{z}$ odczuwaniem więzi z całym wielomilionowym narodem i państwem. Ale na ogół, w przypadku osób badanych, sprawdziła się koncepcja wspólnoty wyobrażonej Andersona (1997), potwierdzonej nie tylko posiadaniem poczucia więzi z narodem Ukrainy i lojalnością wobec państwa, ale również znajomością i akceptacją wartości i idei, kultury symbolicznej danej wspólnoty politycznej.

Ważna obserwacja z badań dotyczy postrzegania pochodzenia etnicznego. Poczucie obywatelskości nie kłóci się, zdaniem badanych, z tożsamością etniczną. W tym sensie poczucie bycia członkiem danego narodu polega na kon-

11 Czy przedstawione tu wypowiedzi i postawy mieszkańców Ukrainy na przykładzie reprezentantów trzech grup etnicznych: Ukraińców, Rosjan oraz Bułgarów żyjących w społecznościach lokalnych Zaporoża wyczerpują zestaw postaw i identyfikacji występujących na badanym obszarze? Trudno jednoznacznie orzec. Bardziej zależało mi na wyrazistości niż na reprezentatywności badania. Wydaje się jednak, że możliwe jest uznanie pewnej reprezentatywności przedstawionych przypadków. Nie jest to cały świat społeczny Ukraińców na pograniczu ukraińsko-rosyjskim, ale są to doświadczenia dla większości wspólne i zapewne typowe. 
stytucyjnym patriotyzmie, szanowaniu wielości kulturowych form życia przy jednoczesnym uspołecznieniu wszystkich obywateli w ramach wspólnej kultury politycznej.

Co to znaczy być Rosjaninem na Ukrainie? Wtaściwie, nic szczególnego. Zwykty obywatel Ukrainy, który nie odczuwa dyskryminacji czy nierównego traktowania. Zwykty cztowiek, który po prostu wie, że jest Rosjaninem czy jeszcze kimś innym. Może komuś powiedzieć, może w pewnych okolicznościach zaznaczyć, że ma przodków takich a takich... W Berdiańsku nie czuje się szczególnego traktowania czy podejścia do takich osób, co maja jakieś korzenie... po prostu... [...] Jaka różnica, czy ja mówię po ukraińsku, czy po rosyjsku, jestem Ukrainka. [...] Zachód Ukrainy czy wschód Ukrainy, ale to caty czas Ukraina (K, R, 44 lata, Berdiańsk).

Powyższy cytat jest jednym z wielu, które pokazują, że mieszkańcy Zaporoża nie czują szczególnej potrzeby zaznaczenia własnej przynależności etnicznej, czują się Ukraińcami i żyją niejako ponad podziałami językowymi, politycznymi czy historycznymi. Jednocześnie własne korzenie etniczne traktują jako osobiste wzbogacenie czy pozytywne wyróżnienie.

Na czym polega idea narodowa? Na świadomości bycia cztonkiem danego narodu. Dopiero wtedy możemy mówić o narodzie. A jezzk itd., to rzeczy ważne, ale nie pierwszorzędne. [...] Nie ma nad czym się zastanawiać, wszystko już zostało powiedziane $w$ konstytucji. Jedyny minus, ale dosyć istotny, polega na problemie elity politycznej, która nie działa $w$ interesach narodu (M, U, 40 lat, Jurjewka).

Problem Ukrainy jest taki, że my się nie czujemy Ukraincami, ale to nie jest nasza wina. Po prostu Ukraina nie potrafita jeszcze stworzyć takich warunków, by można byto powiedzieć my - Ukraińcy. [...] Nasze państwo... Zreszta sama pani wie, paszport mamy, ale nic poza tym. Jak przyjdzie co do czego, ciężko cokolwiek załatwić, liczac na załatwienie sprawy zgodnie z prawem (K, B, 36 lat, Zelenowka).

$\mathrm{W}$ związku z powyższym naród ukraiński przez osoby badane jest pojmowany jako zbiorowość polityczna, w której członków łączy ze sobą wola i wspólne przekonanie, by żyć $\mathrm{w}$ ramach określonego porządku polityczno-państwowego. Naród rozumiany jest, zgodnie z Konstytucją Ukrainy (1996), jako polityczna wspólnota obywateli równych wobec prawa, niezależnie od swej pozycji społecznej, pochodzenia, języka czy religii. Kulturowa różnorodność jest respektowana zarówno przez członków społeczeństwa, jak i przez prawo, a obywatelstwo polityczne jest oddzielone od tożsamości kulturowej bądź etnicznej.

Prawdziwy problem Ukrainy, zdaniem osób badanych, tkwi gdzie indziej i nie jest związany $z$ pojęciem narodu. Chodzi przede wszystkim o makrospołeczne determinanty, mające bezpośredni wpływ na niski poziom patriotyzmu współczesnych Ukraińców. Brak bezpieczeństwa socjalnego jest przyczyną obojętnej lub mniej znaczącej postawy wobec realizacji potrzeb kulturowych. Etniczność bądź poczucie bycia członkiem narodu ukraińskiego staje się wartością dopiero w sytuacji pewnej stabilizacji. W podsumowaniu trzeba powiedzieć, że stosunek obywateli Ukrainy do państwa oraz procesów transformacji 
jest zmienny i i zależny od wyznawanych przez nich ideologii oraz warunków społeczno-politycznych ich życia. Badane osoby zwracały uwagę przede wszystkim na słabość struktur państwowych oraz niski stopień zaufania do elit politycznych, podkreślały potrzebę zrównoważonej polityki państwowej i sprecyzowanej polityki narodowościowej: Brakuje nam mocnych zasad patriotycznych, ale skąd niby powinny sie one pojawić, skoro na Ukrainie nie działaja zasady demokracji (M, U, 40 lat, Jurjewka).

W zachodzących procesach przekształcania świadomości narodowej współczesnych Ukraińców daje się odczuć wpływ wydarzeń historycznych oraz obecnej polityki państwa. To od niej w dużej mierze zależy to, jaki kształt świadomość ta przybierze. Pogląd ten zakłada możliwość określenia wspólnego systemu akceptowanych wartości, który byłby wystarczająco elastyczny i pojemny dla kultur poszczególnych grup etnicznych i stał się podstawą ponadetnicznej struktury o charakterze narodu. Pojęcie narodu na Ukrainie często jest rozumiane zatem inaczej niż w koncepcjach klasycznych, traktujących naród jako byt monoetniczny i monokulturowy (Smith 2007). Naród jest tu pojmowany jako wieloetniczna całość, którą charakteryzuje, a przynajmniej powinna charakteryzować, równowaga między akceptowanymi przez wszystkich wartościami a cechami właściwymi poszczególnym wchodzącym w jego skład kulturom etnicznym. Jedność państwa przejawiająca się we wspólnym obywatelstwie jego członków zostaje uzupełniona i wzbogacona przez uznanie, tolerancję, a nawet zachętę do kultywowania różnorodności kulturowej w obrębie organizmu narodowego. Być może jest to zbyt idealistyczna koncepcja, ale wydaje się ona możliwa do realizacji, jeśli weźmie się pod uwagę zgodność osób badanych w kwestii stworzenia grupy nadrzędnej dla „swoich” i „obcych jako innych”.

\section{BIBLIOGRAFIA}

Altermatt Urs, 1998, Sarajewo przestrzega. Etnonacjonalizm w Europie, tłum. Grzegorz Sowiński, Ośrodek Myśli Politycznej-Znak, Warszwa-Kraków.

Anderson Benedict, 1997, Wspólnoty wyobrażone. Rozważania o źródtach i rozprzestrzenianiu się nacjonalizmu, tłum. Stefan Amsterdamski, Fundacja im. Stefana Batorego-Znak, Warszawa-Kraków.

Babiński Grzegorz, 1997, Pogranicze polsko-ukrainskie. Etnicznośc, zróżnicowanie religijne, tożsamość, Nomos, Kraków.

Babiński Grzegorz, 1999, Pogranicza etniczne i kulturowe, w: Marian Malikowski, Dariusz Wojakowski (red.), Między Polska a Ukraina. Pogranicze - mniejszości, wspótpraca regionalna, Mana, Rzeszów.

Babiński Grzegorz, 2001, Pogranicza stare i nowe, w: Kazimierz Krzysztofek i in. (red.), Pogranicza etniczne w Europie: harmonia $i$ konflikty, Wydawnictwo Uniwersytetu w Białymstoku, Białystok.

Baluk Walenty, 2002, Koncepcje polityki narodowościowej Ukrainy. Tradycje i wspótczesność, Wydawnictwo Uiwersytetu Wrocławskiego,Wrocław.

Bałuszok Wasilij, 1999, Etniczeskoje i nacionalnoje: dinamika $i$ wzaimodiejstwija, „Sociołogija: teorija, mietody, markieting", $\mathrm{nr} 1$.

Berger Peter, Luckmann Thomas, 1983, Społeczne tworzenie rzeczywistości, tłum. Józef Niżnik, Państwowy Instytut Wydawniczy, Warszawa.

Billig Michael, 2008, Banalny nacjonalizm, tłum. Maciek Sekerdej, Znak, Kraków. 
Eberhardt Piotr, 1994, Przemiany narodowościowe na Ukrainie XX wieku, Obóz, Warszawa.

Eberhardt Piotr, 1996, Między Rosją a Niemcami. Przemiany narodowościowe w Europie Środkowo-Wschodniej w XX w., Wydawnictwo Naukowe PWN, Warszawa.

Gellner Ernest, 1991, Narody i nacjonalizm, tłum. Teresa Hołówka, Państwowy Instytut Wydawniczy, Warszawa.

Hrycak Jarosław, 2000, Historia Ukrainy 1772-1999. Narodziny nowoczesnego narodu, tłum. Katarzyna Kotyńska, Instytut Europy Środkowo-Wschodniej, Lublin.

Hrycak Jarosław, 2009, Nowa Ukraina. Nowe interpretacje, Kolegium Europy Wschodniej, Wrocław.

Karnaukh Alla, 2010, Zróżnicowanie kulturowe miasta Berdiańsk na pograniczu ukraińsko-rosyjskim, w: Urszula Abłażewicz-Górnicka i in. (red.), Kapitaty społeczne i kulturowe miast środkowoeuropejskich $i$ wschodnioeuropejskich pograniczy, Wydawnictwo Uniwersytetu w Białymstoku, Białystok.

Karnaukh Alla, 2015, Pomiędzy ukraińskością a sowieckością. Ukraincy, Rosjanie i Bułgarzy na Zaporożu, Nomos, Kraków.

Kasjanow Heorhij, 1999, Teoriji naciji ta nacionalizmu, Łybid', Kyjiw.

Kłoskowska Antonina, 1996, Kultury narodowe u korzeni, Wydawnictwo Naukowe PWN, Warszawa.

Krawczenko Bohdan, 1997, Socialni zminy i nacionalna swidomist' $w$ Ukrajini XX stolittia, Osnowy, Kyjiw.

Krasowska Helena, 2008, Problematyka socjolingwistyczna mniejszości polskiej na potudniowo-wschodniej Ukrainie, w: Lech A. Suchomłynow (red.), Fenomen pogranicz kulturowych: wspótczesne tendencje, Donieck.

Lewandowski Edmund, 2004, Pejzaż etniczny Europy, Muza, Warszawa.

Nikitorowicz Jerzy, 1995, Pogranicze - tożsamość - edukacja międzykulturowa, Trans Humana, Biatystok.

Pawluczuk Włodzimierz, 1998, Ukraina. Polityka i mistyka, Nomos, Kraków.

Sadowski Andrzej, 2006, Obywatelstwo i tożsamość w społeczeństwie zróżnicowanym kulturowo, w: Małgorzata Bienkowska-Ptasznik, Kazimierz Krzysztofek, Andrzej Sadowski (red.), Obywatelstwo i tożsamość $w$ spoleczeństwach zróżnicowanych kulturowo i na pograniczach, t. 1, Wydawnictwo Uniwersytetu w Białymstoku, Białystok.

Smith Antony D., 2007, Nacjonalizm. Teoria, historia, ideologia, tłum. Ewa Chomicka, Sic!, Warszawa.

Szacki Jerzy, 1997, Wstęp. Powrót idei społeczeństwa obywatelskiego, w: Jerzy Szacki (red.), Ani książę, ani kupiec: obywatel. Idea spoteczeństwa obywatelskiego w myśli wspótczesnej, Znak, Kraków.

Szporluk Roman, 2003, Imperium, komunizm i narody. Wybór esejów, tłum. Szymon Czarnik, Andrzej Nowak, Arkana, Kraków.

Wiatr Jerzy J., 1973, Naród i państwo, KiW, Warszawa.

Wojakowski Dariusz, 2005, Chimera czy Proteusz? - o wspótczesnych kształtach i przemianach tożsamości społecznej, w: Tadeusz Lewowicki, Alina Szczurek-Boruta, Barbara Grabowska (red.), Przemiany społeczno-cywilizacyjne i edukacja szkolna. Problemy rozwoju indywidualnego i kształtowania się tożsamości, Oficyna Wydawnicza „Impuls”, Kraków.

Yekelchyk Serhy, 2009, Ukraina. Narodziny nowoczesnego narodu, tłum. Joanna Gilewicz, Wydawnictwo Uniwersytetu Jagiellońskiego, Kraków.

\section{NATIONAL CONSCIOUSNESS IN A CHANGING UKRAINIAN SOCIETY}

\section{Summary}

The article contains a synthesis of analyses and research into national consciousness conducted in the years 2010-2012 among local multiethnic communities in Zaporozhye, which is an area near the Ukrainian-Russian border. In Ukraine, as in the majority of 
post-Soviet states, there are many people who have considerable difficulty in defining their national consciousness: they are undecided as to their national allegiance and are culturally attached to two or more nations or elements of their culture. It is difficult at this time to foresee whether in the end they will declare themselves for one national consciousness to the exclusion of others, or if a new community will emerge. The present processes of forming the national consciousness of contemporary Ukrainians reflect the influence of historical events and the current policies of the state.

\section{Key words/słowa kluczowe}

Ukrainian national consciousness / ukraińska świadomość narodowa; political and cultural (ethnic) concept of a nation / polityczna i kulturowa (etniczna) koncepcja narodu; ethnic group / grupa etniczna; Soviet identity in Ukraine / tożsamość sowiecka na Ukrainie 